\title{
LHT24 Heat-tolerant Tomato Breeding Line
}

\section{H.Y. Hanna ${ }^{1}$, A.J. Adams ${ }^{2}$, and L.L. Black \\ Louisiana State University Agricultural Center, Louisiana Agricultural Experiment Station, Port Sulphur, LA 70083}

Additional index words. Lycopersicon esculentum, determinate

LHT24 is a determinate, red-fruited, heattolerant tomato (Lycopersicon esculentum Mill) developed at the Citrus Research Station, Port Sulphur, La. It was released by the Louisiana Agricultural Experiment Station in 1991 primarily as a source of heattolerant germplasm. It should be useful to other breeders because of its ability to set fruit during periods of high temperature.

\section{Origin}

LHT24 is an inbred line in the $\mathrm{F}_{10}$ generation. This tomato resulted from a cross between 'Fresh Market 9' and 'Tamu Salad-

Received for publication 16 Dec. 1991. Accepted for publication 30 June 1992. Approved for publication by the Director of the Louisiana Agricultural Experiment Station as manuscript no. 91-825524. The cost of publishing this paper was defrayed in part by the payment of page charges. Under postal regulations, this paper therefore must be hereby marked advertisement solely to indicate this fact.

'Red River Research Station.

${ }^{2}$ Citrus Research Station.

${ }^{3}$ Dept. of Plant Pathology and Crop Physiology. ette' (Leeper, 1976; Leeper and Cox, 1986). Generations were advanced by the pedigree breeding method to the $\mathrm{F}_{6}$ and then massed. It was tested in yield trials from the $\mathrm{F}_{7}$ to $\mathrm{F}_{9}$ generations (1989 to 1991) when average day/ night temperatures were $30.7 / 23.8 \mathrm{C}, 31.9$ / $23.4 \mathrm{C}$, and $30.8 / 24.2 \mathrm{C}$ during the 3 -year test period.

\section{Descriptions}

LHT24 has a determinate growth habit with light-green foliage. The plant is intermediate in size with adequate foliage cover for good fruit protection. Nonripe fruit are light green. Fruit are deep oblate to deep globe, and the jointed pedicel separates easily and cleanly

Table 1. Marketable yield and fruit weight of LHT24 and 'Flora-Dade' tomatoes, 1989-91.

\begin{tabular}{lccccccc}
\hline & \multicolumn{2}{c}{$\begin{array}{c}\text { Marketable yield } \\
(\mathrm{kg} / \text { plant })\end{array}$} & & \multicolumn{3}{c}{$\begin{array}{c}\text { Fruit wt } \\
\text { (g/fruit) }\end{array}$} \\
\cline { 2 - 3 } \cline { 5 - 7 } Entry & 1989 & 1990 & 1991 & & 1989 & 1990 & 1991 \\
\hline LHT24 & 1.43 & 1.81 & 2.33 & & 107 & 114 & 146 \\
'Flora-Dade' & 0.17 & 0.30 & 0.94 & & 172 & 170 & 156 \\
LSD (0.05) & 0.35 & 0.36 & 0.44 & & 21.2 & 13.7 & 10.3 \\
\hline
\end{tabular}

from the fruit. External fruit color develops to a uniform bright red. Ripe fruit are firm and have good holding ability on the plant. The stem scar is small, and the blossom end is flat with a stellate to linear pistil scar. Internal fruit color is fair to good, and the walls are of medium thickness.

In replicated trials conducted during Summer (May-September) 1989, 1990, and 1991 in Port Sulphur, LHT24 produced yields ranging from 1.43 to $2.33 \mathrm{~kg} / \mathrm{plant}$. 'FloraDade' produced 0.17 to $0.94 \mathrm{~kg} / \mathrm{plant}$ in the same trials. Fruit weight ranged from 107 to $146 \mathrm{~g}$ compared with 156 to $172 \mathrm{~g}$ for 'FloraDade' (Table 1).

LHT24 is resistant to Verticillium dahliae Kleb. (verticillium wilt), race 1 of Fusarium oxysporum Schlechltend.:Fr. f. sp. lycopersici (Sacc.) W.C. Snyder \& H.N. Hans (fusarium wilt), Meloidogyne incognita (Kofoid \& White) chitwood (root knot nematode), Stemphylium solani G.F. Weber (gray leaf spot), and Alternaria alternata (Fr.:Fr.) Keissl. f. sp. lycopersici Grogan et al. (alternaria stem canker).

\section{Availability}

Seeds are available to breeders from H.Y.H., Red River Research Station, P.O Box 8550, Bossier City, LA 71113-8550.

\section{Literature Cited}

Leeper, P.W. 1976. Tamu Saladette, a new dual purpose, fresh market and/or processing tomato. Tomato Genet. Coop. Rpt. 27, Appendix 63

Leeper, P.W. and E.L. Cox. 1986. 'Fresh Market 9' tomato. HortScience 21:156. 